\title{
An Econometric Analysis of the Link between Biodiesel Demand and Malaysian Palm Oil Market
}

\author{
Shri Dewi A/P Applanaidu (Corresponding author) \\ College of Arts and Sciences, Economics Building, Universiti Utara Malaysia \\ 06010 Sintok, Kedah Darul Aman, Malaysia \\ Tel: 60-1-9565-9786 E-mail: dewi@uum.edu.my \\ Prof. Dr. Fatimah Mohamed Arshad \\ Institut Kajian Dasar Pertanian dan Makanan \\ Faculty of Economics and Management, University Putra Malaysia, Malaysia \\ E-mail: fatimah@econ.upm.edu.my \\ Prof. Dr. Mad Nasir Shamsudin \\ Faculty of Agriculture, Universiti Putra Malaysia, Malaysia \\ E-mail: nasir@econ.upm.edu.my \\ Dr. Amna Awad Abdel Hameed \\ Institut Kajian Dasar Pertanian dan Makanan \\ University Putra Malaysia, Malaysia \\ E-mail: amna.awad@gmail.com
}

\begin{abstract}
The objective of this study is to describe the important factors affecting Malaysian palm oil industry especially biodiesel demand. To that end a market model representing palm oil production, import, world excess demand, domestic consumption, export demand, rest of the world excess supply and palm oil prices is formulated. A system of equations of eight structural equations and four identities is estimated by two stage least squares method using annual data for the period 1976-2008. The domestic price equation is formed to investigate the link between biodiesel demand and the Malaysian palm oil market. The domestic price is significantly affected by Malaysian ending stock, world palm oil price, biodiesel demand and lagged domestic price. The elasticity of Malaysian palm oil domestic price with respect to biodiesel demand is then obtained. Results suggest that biodiesel demand has a positive impact on the Malaysian palm oil domestic price. Thus, significant growth in biodiesel demand is important in explaining Malaysian palm oil price determination.
\end{abstract}

Keywords: Biodiesel demand, Domestic demand, Domestic price, Export demand of palm oil, Palm oil supply, Structural equations, Two stage least squares

\section{Introduction}

Over a few decades of development, the Malaysian palm oil industry has succeeded to be a powerful force in the global oils and fats economy. Investments in oil palm planting have been growing, because of its economic advantage, leading to expansion in output that surpassed the average global oils and fats growth. With practical and tempting choice to importers in terms of price competitiveness and its superior attributes for various edible and non-edible applications, its secured supply availability, Malaysia, now tops the list of the palm oil exporters. The demand for palm oil is expected to be further accelerated with the flourishing biofuels industry both locally and at the global levels as it is anticipated to become the number one feedstock for biodiesel production due to its price advantage.

The industry also plays a significant role in the Malaysian economy as palm oil accounts for two thirds of the country's agricultural export value and about one third of its commodity export value (Bank Negara Malaysia, 
2009). The development of the Malaysian biofuel industry boosted the importance of this commodity being an economically ideal feedstock for biodiesel production. Moreover, the industry, including the downstream sectors, provides employment to 860 thousand people, both directly and indirectly (MPOC and MPOB, 2008). Many studies were conducted to investigate the palm oil market but since monitoring of any commodity market is an evolutionary procedure, especially the Malaysian palm oil market which witnessed many recent developments, it is realized that a timely study to investigate the changes in market variables and the impact of these changes on the industry is very important. Thus, this paper attempts to estimate and analyse the relationship between biodiesel demand and the Malaysian palm oil market and to provide an updated tool for policy makers.

The remainder of the paper is organized as follows: Section 2 briefly reviews the literature on previous studies on palm oil industry and the methodologies used for examining the market variables behaviour, Section 3 is the model specification, Section 4 reports and discusses the results while a summary and some conclusions are presented in Section 5.

\section{Literature Review}

The relatively simple generalized theoretical model widely has been applied to most of the agricultural commodities (such as palm oil, soybean oil, rubber and cocoa). In Malaysia, it also been applied to analyze and model the palm oil, rubber and cocoa market. In terms of palm oil, the structure is refined to ease the penetration in the international market. Previous work of Malaysian palm oil market was done by Yusoff (1988), Au and Boyd (1992), Shamsudin and Arshad (1993) and Talib and Darawi (2002). There is also a study on factors affecting palm oil prices and forecasting palm oil prices using various techniques (Arshad and Ghaffar, 1987; Shamsudin, Mohamed and Arshad, 1988 and Shamsudin, Arshad, Mohamed and Lubis, 1994). Yusoff (1988) incorporated export tax and exchange rate in his work. Later a study by Abdullah, Amiruddin and Ibrahim (1993) simulate the Malaysian palm oil market using all the factors affecting palm oil in Malaysia. Shamsudin et al. (1994) expanded the earlier works on palm oil model by differentiating supply response of estate and smallholder sectors and diversify nature of export market. Alias, Jani and Abdullah (1999) have done a simulation study of the impact of liberalization crude palm oil imports from Indonesia. Description of the national model on Malaysian palm oil market between 1970 and 1999 by identifying the important factors that affecting the market was done by Talib and Darawi (2002). The domestic features as well as imports and exports are included to measure its performance in the international trade. Alias and Tang (2001) have analysed the supply response of the Malaysian palm oil market using Engle and Granger (1987) cointegration and error correction approach. A study by Abdullah, Abas and Ayatollah (2007) on the impact of palm oil based biodiesel demand on palm oil price is a new attempt to include biodiesel demand in the price equation by using Time Varying Parameter.

A simulation study on the impact of the exchange rate variation was done by Alias, Shri Dewi and Ali (2006). There is also a study on the impact of structural change of the Indonesian production on the Malaysian palm oil market (Shri Dewi, Alias \& Ali, 2007) between 1976 and 2005. The study of the impact of liberalizing trade on Malaysian palm oil was done by Talib, Jani, Mamat and Zakaria (2007). Later, Shri Dewi and Alias (2009) analysed the rising importance of Indonesian palm oil production with the impact on the Malaysian palm oil market extending the previous study period in Shri Dewi et al. (2007) from 2005 till 2008. One of the most recent studies on Malaysian palm oil market model by Shri Dewi et al. (2009a) ignored the importance of biodiesel demand factor in the market model. There are also studies using the application of a system dynamics approach to the Malaysian palm oil industry but it has been limited with the exception of Kennedy (2006) and Yahaya et al. (2006). Both these studies examine the biodiesel, crude palm oil and petroleum price linkages. The studies that used the combination of econometric and system dynamics approach on Malaysian palm oil market was done by Shri Dewi et al. (2009b and 2010).

Limitations of previous research are threefold. First, the previously noted studies ignored the importance of biodiesel demand in Malaysian palm oil market model. Eventhough Abdullah et al. (2007) included this variable in the model, but it is only limited in the price equation. The Time Varying Parameter model was adopted in their study. Secondly, most of the previous Malaysian palm oil studies (Abdullah et al., 1993; Talib and Darawi, 2002; Alias et al. 2006; Shri Dewi et al., 2007 and Talib et al., 2007) have ignored the role of stationarity and cointegration as a prerequisite test before proceeding to the simultaneous equation estimation procedure. Over the time, most of the macroeconomic variables show a trending behaviour. This phenomenon is known as nonstationary time series in econometrics. There might be spurious regression due to the presence of non-stationary variables (Granger and Newbold, 1974). It is inappropriate to make any valid statistical inference with the nonstationary data. Based on these current development, there are few empirical studies applied the simultaneous equation model using 2SLS (Robledo, 2002; Sekhar, 2003a; Sekhar, 2003b; Song, 2006 and 
Sekhar, 2008). As such, the Malaysian palm oil market model will be estimated using this procedure. Finally, we are unaware of any studies using more recent data in a simultaneous equation models to examine the role of biodiesel on the Malaysian palm oil market especially the inclusion of biodiesel demand variable in the model.

\section{Model Specification}

The basic market model which was proposed by Labys (1973) was used to develop the framework in this study. The construction of the market model can be summarized into four equations which consists supply $\left(\mathrm{Q}_{\mathrm{t}}\right)$, demand $\left(\mathrm{D}_{\mathrm{t}}\right)$, price $\left(\mathrm{P}_{t}\right)$ and stock or inventory $\left(\mathrm{I}_{\mathrm{t}}\right)$ as an identity equation.

$$
\begin{aligned}
& Q_{t}=q\left(Q_{t-1}, P_{t-1}, N_{t}, Z_{t}\right) \\
& D_{t}=d\left(D_{t-1}, P_{t}, P_{t}^{c}, A_{t}, T_{t}\right) \\
& P_{t}=p\left(P_{t-1}, I_{t}\right) \\
& I_{t}=I_{t-1}+Q_{t}-D_{t}
\end{aligned}
$$

where;

$\mathrm{Q}_{\mathrm{t}}=$ commodity supply

$\mathrm{D}_{\mathrm{t}}=$ commodity demand

$\mathrm{P}_{\mathrm{t}}=$ commodity price

$\mathrm{I}_{\mathrm{t}} \quad=$ inventory or stock

$\mathrm{P}_{\mathrm{t}-\mathrm{i}}=$ prices with lag distribution

$\mathrm{N}_{\mathrm{t}}=$ natural factors

$\mathrm{Z}_{\mathrm{t}}=$ policy variables influencing supply

$\mathrm{P}_{\mathrm{t}}^{\mathrm{c}}=$ prices of substitute commodities

$\mathrm{A}_{\mathrm{t}}=$ economic activity level or income

$\mathrm{T}_{\mathrm{t}}=$ technical factors

According to Labys and Pollak (1984), it is assumed that in the system equation, prices adjust to clear the market. Supply of the commodity depends on the lagged supply, lagged price, natural factors and policy variables. Demand is being dependent on lagged demand, own price, prices of one or more substitute commodities, level of economic activity and technical factors. Lagged price and changes in inventory can be used to explain the price. Since the supply process normally uses the general class of distributed lag functions so the lagged price variables are included. The market model is closed using an identity which equates inventories with lagged inventories plus quantity supplied minus quantity demanded.

A structural econometric model of the Malaysian palm oil industry is used to estimate the relevant parameters. The structural models reported in various studies (Shamsudin et al., 1988; Shamsudin et al., 1993; Shamsudin et al., 1994; Alias et al., 1999; Talib and Darawi, 2002; Alias et al., 2006; Taylor et al., 2006; Park and Fortenberry, 2007; Talib et al., 2007; Shri Dewi et al., 2007 and Shri Dewi et al., 2008, 2009 \& 2009a) are modified for this purpose. The structural econometric model of the Malaysian palm oil industry specified in this study consists of eight behavioural equations and four identities.

\subsection{Palm Oil Production}

The model specification used in estimating the supply response for Malaysian palm oil production is based on the model developed by Alias and Tang (2005), Alias et al. (2006), Shri Dewi et al. (2007), Shri Dewi et al. $(2008,2009 \& 2009 a)$. The supply of CPO is assumed to depend on the ratio of the palm oil current price and natural rubber, ratio price of palm oil and natural rubber lagged three years, government development expenditure on agriculture, interest rate and time trend. Since supply of CPO is an unknown quantity, it is assumes to follow the stock adjustment process and we have another variable of lag one year of supply. Palm oil supply can be specified as follows;

$$
\mathrm{POQ}_{\mathrm{t}}=\alpha_{0}+\alpha_{1} \text { CPOPNRP }_{\mathrm{t}}+\alpha_{2} \mathrm{CPOPNRP}_{\mathrm{t}-3}+\alpha_{3} \mathrm{IR}_{\mathrm{t}-3}+\alpha_{4} \mathrm{GOVDE}_{\mathrm{t}-3}+\alpha_{5} \mathrm{~T}+\alpha_{6} \mathrm{POQ}_{\mathrm{t}-1}+\mu_{1 \mathrm{t}}
$$

where;

$$
\begin{aligned}
& \mathrm{POQ}=\text { palm oil production (tonnes) } \\
& \mathrm{CPOPNRP}_{\mathrm{t}} \quad=\text { relative price of palm oil to rubber } \\
& \mathrm{CPOPNRP}_{\mathrm{t}-3} \quad=\text { relative price of palm oil to rubber lag } 3 \text { years }
\end{aligned}
$$




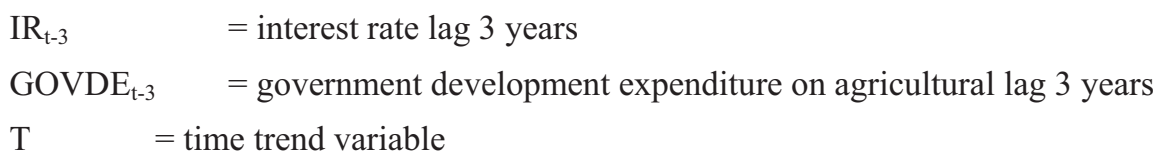

Equation (5) suggests that the crude palm oil production would be positively related to the CPOPNRP ${ }_{t}$, CPOPNRP $\mathrm{t}_{\mathrm{t}-3}, \mathrm{GOVDE}_{\mathrm{t}-3}, \mathrm{~T}$ and $\mathrm{POQ}_{\mathrm{t}-1}$ whereas $\mathrm{IR}_{\mathrm{t}-3}$ expected to be negative.

\subsection{Malaysian Import}

According to Labys, (1973) in order to reflect trading in the international market a country model should include exports as well as imports. The amount of palm oil imported by Malaysia is small. The import equation is adopted from Abdullah et al. (1993), Alias et al. (1999), Talib and Darawi (2002), Alias et al. (2006), Taylor et al. (2006), Talib et al. (2007), Shri Dewi et al. (2007), Shri Dewi et al. (2008, 2009 \& 2009a). Thus, the desired Malaysian import equation of palm oil can be postulated as follows:

$$
\mathrm{CPOM}_{\mathrm{t}}=\beta_{0}+\beta_{1} \mathrm{POWP}_{\mathrm{t}}+\beta_{2} \mathrm{PSB}_{\mathrm{t}}+\beta_{3} \mathrm{GDP}_{\mathrm{t}}+\beta_{4} \mathrm{STOCK}_{\mathrm{t}}+\beta_{5} \mathrm{CPOM}_{\mathrm{t}-1}+\mu_{2 \mathrm{t}}
$$

where;

$$
\begin{array}{ll}
\mathrm{CPOM}_{\mathrm{t}} & =\text { Malaysian import demand of palm oil (tonnes) } \\
\mathrm{GDP}_{\mathrm{t}} & =\text { Malaysian GDP at } 2000 \text { Prices (RM million) } \\
\mathrm{POWP}_{\mathrm{t}} & =\text { real world price of palm oil (USD/tonne) } \\
\mathrm{STOCK}_{\mathrm{t}} & =\text { beginning Stock (tonnes) }
\end{array}
$$

It is expected, that the signs of the coefficients for palm oil world price, price of soybean, Malaysian GDP and lagged one year of palm oil import expected to be positive. It is also expected that the signs for stock of palm oil to be negative. This is because as Malaysian stock levels of palm oil become lower, the imports of palm oil tend to increase.

\subsection{World Import}

Meanwhile, the world import or world excess demand is determined by world price, soybean price, world income, world stock and lagged one year of world palm oil import. This is shown as follows:

$$
\mathrm{WEXCDD}_{\mathrm{t}}=\omega_{0}+\omega_{1} \mathrm{POWP}_{\mathrm{t}}+\omega_{2} \mathrm{PSB}_{\mathrm{t}}+\omega_{3} \mathrm{WGDPN}_{\mathrm{t}}+\omega_{4} \mathrm{WSTOCK}_{\mathrm{t}}+\omega_{5} \mathrm{WEXCDD}_{\mathrm{t}-1}+\mu_{3 \mathrm{t}}
$$

where;

$$
\begin{aligned}
& \text { WEXCDD }_{\mathrm{t}}=\text { world excess demand (tonnes) } \\
& \text { WGDPN }_{\mathrm{t}} \quad=\text { world GDP at } 2000 \text { prices (USD billion) }
\end{aligned}
$$

\subsection{Domestic Demand}

Domestic demand is assumed to depend on the real domestic price of palm oil, domestic economy activity which is represented by real GDP, real domestic price of soybean oil and Malaysian population. The domestic consumption equation is renamed as follows;

$$
\mathrm{DCCPO}_{\mathrm{t}}=\gamma_{\mathrm{o}}+\gamma_{1} \mathrm{CPOP}_{\mathrm{t}}+\gamma_{2} \mathrm{GDP}_{\mathrm{t}}+\gamma_{3} \mathrm{PSB}_{\mathrm{t}}+\gamma_{4} \mathrm{MPOP}_{\mathrm{t}}+\gamma_{5} \mathrm{DCCPO}_{\mathrm{t}-1}+\mu_{4 \mathrm{t}}
$$

where;

$\mathrm{DCCPO}_{\mathrm{t}}=$ domestic palm oil consumption (tonnes)

$$
\begin{array}{ll}
\mathrm{CPOP}_{\mathrm{t}} & =\text { real Malaysian Price of Palm Oil (RM/tonne) } \\
\mathrm{PSB}_{\mathrm{t}} & =\text { real world price of soybean oil (USD/tonne) } \\
\mathrm{MPOP}_{\mathrm{t}} & =\text { Malaysian population (million people) }
\end{array}
$$

$\mathrm{DCCPO}_{\mathrm{t}}$ suggests that, the higher the price received, the less will be the amount of palm oil consumed in Malaysia. This is also based on the law of demand, where the consumers will act negatively to the increase in the palm oil price. The real price of Malaysian palm oil were calculated by deflating the nominal prices by the consumer price index (CPI); 2000=100. The real GDP variable represents as the proxy of Malaysian economic activity and therefore it should be positive. This function also suggests that domestic consumption positively related to prices of soybean (assumed to be a substitute commodity for palm oil). However, according to Talib and Darawi (2002), real domestic price of coconut oil was used as a substitute to palm oil. In this study, only the real price of soybean oil is used due to the closest feedstock competitor to palm oil. The world CPI was used as 
the deflator for the world prices of soybean oil. Population is expected to be positive relationship. Finally lagged one period of domestic demand is used as variable to add the dynamic to the model.

\subsection{Export Demand of Palm Oil}

The export demand for palm oil shown in equation (9) as follows:

$$
\mathrm{XPO}_{\mathrm{t}}=\chi_{0}+\chi_{1} \mathrm{POWP}_{\mathrm{t}}+\chi_{2} \mathrm{PSB}_{\mathrm{t}}+\chi_{3} \mathrm{WGDPN}_{\mathrm{t}}+\chi_{4} \mathrm{ER}_{\mathrm{t}}+\chi_{5} \mathrm{XPO}_{\mathrm{t}-1}+\mu_{5 \mathrm{t}}
$$

where;

$\mathrm{XPO}_{\mathrm{t}}$

$$
\text { = export demand of palm oil (tonnes) }
$$

$\mathrm{ER}_{\mathrm{t}}$

$$
=\text { exchange rate }(\mathrm{RM} / \mathrm{USD})
$$

Equation (9) indicates that palm oil export demand is modelled as a function of real world price of palm oil, price of other substitutes (price of soybean oil), real world GDP, exchange rate and lagged one year of the endogenous variable. Export of palm oil is postulated to depend on prices. In terms of POWP it is expected to be negatively related to XPO. This suggest that the higher the price received, the less will be the amount of palm oil will be exported. The substitute for palm oil plays an important role in determining XPO, similar to Alias (1988), Shamsudin et al. (1994), Alias et al. (1999), Alias et al. (2006) and Shri Dewi et al. (2007). As if the soybean price falls, the demand for soybean will increase and demand for palm oil will decrease. A world economic activity is represented by real world GDP. The impact of exchange rates is measured by the Ringgit Malaysia (RM) over U.S dollar (USD). It is expected to be a positive relationship. This variable also been included by most of the studies by Alias (1988), Yusoff (1988), Alias et al. (1999), Shri Dewi et al. (2007), Talib et al. (2007), Park and Fortenberry (2007), Shri Dewi et al. (2008, 2009 \& 2009a). Finally the lagged dependent variable is used as an independent variable to capture dynamics in the use of palm oil export.

\subsection{Rest of the World Excess Supply}

Meanwhile, the rest of the world excess supply is affected by palm oil world price, rest of the world palm oil supply and the lagged 1 year of the rest of the world excess supply (see Shamsudin, Arshad and Fuziah, 1997). All these factors have positive impact on the world excess supply. The rest of the world excess supply can be specified as follows;

$$
\text { ROWEXCSS }_{\mathrm{t}}=\varphi_{0}+\varphi_{1} \text { POWP }_{\mathrm{t}}+\varphi_{2} \text { ROWPOQ }_{\mathrm{t}}+\varphi_{3} \text { ROWEXCSS }_{\mathrm{t}-1}+\mu_{7 \mathrm{t}}
$$

where;

$$
\begin{array}{ll}
\text { ROWEXCSS }_{\mathrm{t}} & =\text { rest of the world excess supply (tonnes) } \\
\text { ROWPOQ }_{\mathrm{t}} & =\text { rest of the world production (tonnes) }
\end{array}
$$

\subsection{Domestic Price}

The domestic price equation can be specified as follows;

$$
\mathrm{CPOP}_{\mathrm{t}}=\varsigma_{0}+\varsigma_{1} \mathrm{STOCK}_{\mathrm{t}}+\varsigma_{2} \mathrm{PSB}_{\mathrm{t}}+\varsigma_{3} \mathrm{POWP}_{\mathrm{t}}+\varsigma_{4} \mathrm{BDDD}_{\mathrm{t}}+\varsigma_{5} \mathrm{CPOP}_{\mathrm{t}-1}+\mu_{8 \mathrm{t}}
$$

where;

$\mathrm{CPOP}_{\mathrm{t}} \quad=$ domestic price of palm oil

STOCK $_{\mathrm{t}} \quad=$ ending stock of CPO (tonnes)

$\mathrm{BDDD}_{\mathrm{t}} \quad=$ biodiesel demand (export volume of biodiesel in tonnes)

The inclusion of stock variable indicates the presence of stock together with time may influence the local price of palm oil (Abdullah et al., 1993). There is expected a negative relationship between stock and the price of palm oil. Another affecting variable could be the soybean oil price (Alias, 1988; Yusoff, 1988; Abdullah et al., 1993; Alias et al., 1999; Alias et al. 2006; Abdullah et al., 2007; Shri Dewi et al., 2007; Talib et al., 2007; Shri Dewi et al., 2008, 2009 \& 2009a). Soybean and palm oils are the two examples of agricultural commodities that have similar characteristics and are substitutable in many applications. According to Abdullah et al. (2007) the prices are highly correlated with the highest correlation index of 0.82 compared with any other oils and fats except Palm Kernel Oil (PKO). Another reason is that their relationship are very close whenever there is an increase in soybean oil price, the palm oil price follows. Furthermore, the soybean oil price also quoted in the Chicago Board of Trade (СBOT) futures market and used as a reference or benchmark by these oils and fats. As such this is the reason that soybean oil price is selected compared to any other substitutes. It is expected a positive relationship between palm oil price and soybean oil price. Biodiesel demand has been included following Abdullah et al. (2007) in a Time Varying Parameter model. This is also an attempt to include biodiesel demand 
in the Malaysian palm oil market model. It is expected a positive relationship. Finally the lagged of one period of palm oil price is added due to the market price as a result of partial adjustment process.

\subsection{World Price}

The world price of palm oil is determined by the world supply and demand. The world price equation can be specified as follows:

$$
\mathrm{POWP}_{\mathrm{t}}=\Pi_{0}+\Pi_{1} \mathrm{PSB}_{\mathrm{t}}+\Pi_{2} \mathrm{WGDPN}_{\mathrm{t}}+\Pi_{3} \mathrm{WSTOCK}_{\mathrm{t}}+\Pi_{3} \mathrm{POWP}_{\mathrm{t}-1}+\mu_{9 \mathrm{t}}
$$

where;

$$
\text { WSTOCK }_{\mathrm{t}} \quad=\text { world stock of palm oil (tonnes) }
$$

Equation (12) suggests that POWP would be positively related to the price of its substitute; soybean, WGDPN, POWP $_{\mathrm{t}-1}$ and a negative relationship with WSTOCK. As soybean oil is a competitor to palm oil, soybean price would have a positive relationship with POWP. An increase in world supply indirectly affect domestic price through POWP.

\subsection{Closing Identities}

The introduction of four identities (Malaysian stock, Malaysian excess supply, world excess supply and world stock) will complete the system. The four identities are specified as follows:

$$
\begin{gathered}
\text { STOCK }_{\mathrm{t}} \quad=\mathrm{STOCK}_{\mathrm{t}-1}+\mathrm{POQ}_{\mathrm{t}}+\mathrm{CPOM}_{\mathrm{t}}-\mathrm{DCCPO}_{\mathrm{t}}-\mathrm{XPO}_{\mathrm{t}} \\
\text { MEXCSS }_{\mathrm{t}}=\mathrm{POQ}_{\mathrm{t}}-\mathrm{DCCPO}_{\mathrm{t}} \\
\mathrm{WEXCSS}_{\mathrm{t}}=\mathrm{MEXCSS}_{\mathrm{t}}+\text { ROWEXCSS }_{\mathrm{t}} \\
\text { WSTOCK }_{\mathrm{t}}=\text { STOCK }_{\mathrm{t}}+\text { ROWSTOCK }_{\mathrm{t}}
\end{gathered}
$$

where;

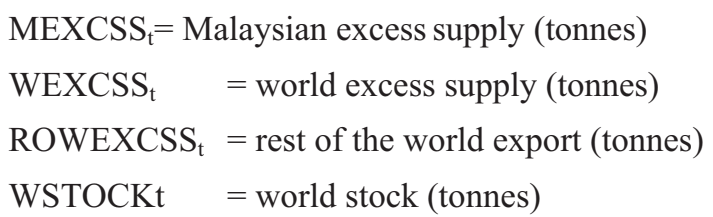

The total Malaysian ending stock of palm oil is defined as the sum of beginning stocks, production and imports minus domestic consumption and export demand. The Malaysian excess supply is of Malaysian supply minus the domestic consumption. The world excess supply or world export is composed of the summation of from Malaysian palm oil and the rest of the world export. Finally world stock is the summation of Malaysian stock and rest of the world stock.

Before carrying out the cointegrating test and estimation, indentification is verified by calculating order and rank conditions. Since the model meets these conditions, it can be solved with a unique solution, then the cointegrating test will be carried out. The sample period for this study was from 1976 to 2008. The data were extracted from publications of the Department of Statistics of Malaysia, Malaysian Palm Oil Board and International Financial Statistics of the International Monetary Fund. The two-stage least squares estimation was applied to the specified model.

\section{Model Estimation}

The estimates of the Malaysian palm oil market model are presented in Table 1. The non-linear 2SLS estimates obtained from this study are quite satisfactory in terms of high $\mathrm{R}^{2}$, significance of the coefficients of the variables and the correct signs. The relevant DW-statistics and h-statistics shows that the autocorrelation is not serious. The results suggest that the production of crude palm oil in Malaysia is determined by the ratio of its price with rubber, interest rate, government development expenditure on agriculture and time trend. All of the estimated coefficients in the supply equation of palm oil have the expected signs. The relative price of palm oil and rubber lagged three years is significant at the 10 percent level even though the current relative price is found not to be important determinant of the palm oil production. An increase of one percent in the relative price of lag three years leads to a 0.0001 percent increase in palm oil production. This finding is consistent with the finding in Alias et al. (2001) and Alias and Tang (2005) study on supply response of Malaysian palm oil producers and a study by Remali et al. (1998) on Malaysian cocoa supply response. This reflects the importance of this variable at the time the investment is made. Oil palm, rubber and cocoa are competitors in terms of land use in the Malaysian context. In this study, the relative price of palm oil with respect to the price of rubber was chosen as it 
is the main substitute crop. The increase in this relative price will increase the palm oil production due to higher price in palm oil.

The interest rate variable is included to account for the cost of borrowing and it is found to be negative according to the theory. A one percent increase in the rate of interest leads to 0.0002 percent decrease in the palm oil production three periods ahead. Planting is discouraged with the negative effect on working capital due to increase in interest rate. According to Alias and Tang (2005), there are two major findings, the first; monetary policy does has an impact on the planting (investment) decisions. The planters are encouraged to replant old trees or to replace rubber trees with oil palm if there is a lower cost of borrowing which is relevant within the current context. The second approach is to narrow the gap between potential yield and realized yield. The national average yield is about 1.3 tonnes of palm oil per hectare and this yield is less than that achieved by a well managed plantation. Increasing the rate of replanting is more effective long run strategy now where a large proportion of trees planted 25 to 30 years ago are yet to be replanted and this indicates that monetary policy does impact on the investment decisions. A lower cost of borrowing would encourage planters to replant old trees or to replace rubber trees with oil palm.

Government expenditure a proxy for government support is positively associated with the supply of palm oil which mainly benefits the smallholding sector. Government expenditure acts as a shifter variable in the supply function of CPO. A one percent increase in the government expenditure three periods ago leads to a 0.0003 percent increase in palm oil production. It is significant at the five percent level and gives empirical support for government intervention and support in agriculture. The time trend $(\mathrm{T})$ is significant at the 1 percent level, suggesting CPO production is trending upward due to technology innovation in cultivation, management and development of high yielding also contributed to the increase in palm oil production.

The estimates obtained for the import demand are consistent with a priori expectations. As expected, Malaysian imports of $\mathrm{CPO}$ was negatively related to the price of world palm oil but positively related to price of soybean. An increase of one percent in palm oil world price will decrease 8.2 percent in the palm oil import. This result was supported by results by Talib and Darawi (2002). The coefficient of the price of soybean is found to be negative even though statistically insignificant. The coefficient of the Malaysian GDP is found to be positive. Its elasticity indicating that a one percent increases in GDP would increase imports of palm oil by 3.76 percent. As expected, the coefficient of beginning stocks has a negative sign, even though it is statistically insignificant. A 1 percent increase in beginning stocks could decrease Malaysian imports of palm oil by 0.85 percent. Therefore, imports provide substitutes for decreasing stocks.

The empirical estimates of world excess demand suggests that the primary factors affecting changes in world excess demand are world price, world price of soybean and lagged one year of world import. The own price elasticity is 0.3643 whereas the finding by Shamsudin et al. (1997) shows the elasticity at the value of 0.278 . The world income was significant at one percent level and had the expected sign. The coefficient on lagged world import demand is significant at one percent level with the adjustment coefficient being approximately 0.4957 indicates a relatively moderate adjustment to the equilibrium level.

The domestic demand equation in this research is based on Marshallian demand function. The domestic demand empirically affected by the own price, Malaysian GDP, price of soybean and lagged domestic demand. All of the variables are significant at least at the 5 percent level, except price of substitute (soybean). The adjustment coefficient being 0.5035 indicate a moderate adjustment to the equilibrium level. An increase in the own price by one percent would decrease domestic utilization by 0.16 percent. These results shows an inelastic of own price and also supported by Talib and Darawi (2002) with 0.388. In Shamsudin et al. (1997) the elasticity is 0.242. In the short-run, given a one percent increase in Malaysian GDP, the domestic consumption would only increase by 0.63 percent. The coefficient of the current price of soybean oil is positive follows the expected sign. However, this coefficient is not statistically significant, implying that the consumption level of palm oil does not merely depend on the soybean price. The current level of consumption also relies on one year lagged consumption. The coefficient of lagged domestic demand also significant indicating that lagged adjustment model is appropriate. The adjustment coefficient 0.50 suggesting that adjustment to the desired level of domestic consumption is rapid at about 50 percent per year. The results are consistent with earlier studies such as that by Yusoff (1988), Alias et al. (1999) and Shamsudin et al. (1988), Alias et al. (2006) and Shri Dewi et al. (2007).

A perusal of these results indicates that the export demand function has a reasonably good fit and all the variables have expected signs and significant coefficients. The coefficients for own and substitute prices, exchange rate, world income and lagged endogenous variable are significant at least at 5 percent level. The own price elasticity is -0.3236 . The results confirm the findings by Shamsudin et al. (1993) and Shamsudin et al. 
(1988) that the export demand for agricultural demand is inelastic. The Malaysian financial exchange rate is also important as a determinant of the palm oil export. Malaysian palm oil export can be increased by about 0.3163 percent for every one percent increase in the Malaysian Ringgit-US Dollar exchange rate. The coefficient of palm oil export lagged one year is statistically significant and also showing that the adjustment to the desired level of exports is small (0.3895) due to the large amount of Malaysian palm oil exports, i.e. on average more than 90 percent of total production is exported every year. This result confirms the finding in Yusoff (1988) and Talib et al. (2007).

The rest of the world export is mainly determined by the production in the rest of the world. The production variable is significant at the one percent level. The world price variable having the expected sign but it is not statistically significant. The coefficient of rest of the world export lagged one year also has the expected sign but not statistically significant. The speed of adjustment shows that the adjustment to the desired level of rest of the world exports is very big; 0.8473 .

All the estimated coefficients in the domestic price equation have the expected signs. The price flexibilities with respect to stock and world price are -0.1042 and 0.3652 , respectively. The biodiesel demand variable is included as a proxy to model the effect of rising importance of biodiesel demand on Malaysian palm oil industry as was incorporated by Abdullah et al. (2007). The coefficient of this variable is 0.2371 which is statistically significant at 1 percent level and follows the correct sign. The coefficients on lagged prices indicate that the adjustment price to the equilibrium is relatively fast (0.8792). The results are consistent with the finding of Shamsudin et al. (1993) and Hwa (1979) that stock disequilibrium determines the changes in primary commodity prices and also the speed of adjustment is generally faster for agricultural commodities. The speed of adjustment in Abdullah and Lazim (2006) also found to be consistent with this study; 0.6618.

In the case of the equation for the palm oil world price, it is found that all the variables could explain the variation; price of soybean, world GDP, world stock and lagged dependent variable. Price of soybean is found to be significant at 5 percent level where this confirms the belief that soybean oil is palm oil's main substitute and both oils compete in the international fats and oils market. The result is consistent with Yusoff (1988) and Talib et al. (2007). Thus, a one percent increase in the price of soybean would result a 0.2066 percent increase in the palm oil world price. The other variable, the world income is significant at one percent level.

Overall, the estimation results of the Malaysian palm oil market model are statistically acceptable and have identified many important factors related to supply, domestic demand, export demand and prices (domestic and world). Some of the coefficients are found not to be significant but we retained them on a priori ground, i.e. we believe that the variables are relevant, but because of possible data and econometric problem, accurate estimates are not possible.

\section{Conclusion}

The central theme of this paper is to develop a Malaysian market model for the palm oil industry. The results indicate that the Malaysian palm oil price function has a reasonably good fit and all the variables have expected signs and significant coefficients except stock of palm oil with correct sign but insignificant value. The inclusion of new element of biodiesel demand results show that this variable has a significant effect on the palm oil prices. This effect can be transmitted to palm oil production, domestic consumption, Malaysian excess supply, stock, world stock, world palm oil price, world excess demand, palm oil export, import, world excess supply and rest of the world excess supply. This study also shows how energy market and agricultural market especially palm oil are intertwined because of biodiesel demand. To more fully understand the overall impact of biodiesel demand on Malaysian palm oil market, future research includes conducting counterfactual analysis of the change of this variable on the main endogenous variables.

\section{References}

Abdullah, R., Abas, R., and Ayatollah, K. (2007). Impact of Palm Oil-based Biodiesel Demand on Palm Oil Price. Oil Palm Industry Economic Journal, 7(2), 19-27.

Abdullah, R., Amirudin, M.N and Ibrahim, A. (1993). An Econometric Model Simulating the Malaysian Palm Oil Market. PORIM Buletin, 26, 27-38.

Abdullah, R., and Lazim, M.A. (2006). Production and Price Forecast for Malaysian Palm Oil. Oil Palm Industry Economic Journal, 6(1), 39-45.

Alias, M. H., Shri Dewi, S., and Ali, A. M. (2006). Variasi Kadar Pertukaran Matawang dan Harga Minyak Sawit: Analisis Berdasarkan Satu Model Struktur. Jurnal Ekonomi Malaysia, 40, 3-25. 
Alias, M.H and Tang, T.C. (2005). Supply Response of Malaysian Palm Oil Producers: Impact of Interest Rate Variations. Oil Palm Industry Economic Journal, 5(2), 11-22.

Alias, M.H. (1988). Pembinaan dan Pemilihan Model Respon Penawaran Pengeluaran Getah Asli. Jurnal Ekonomi Malaysia, 18, 3-25.

Alias, M.H., Ali, A.M., and Rahman, M. A. (2001). The Impact of Government Policy on the Supply Response of Malaysian Palm Oil, Rubber and Cocoa Producers. Utara Management Review, 2(1), 41-64.

Alias,M.H., Jani, M.F.M and Abdullah, R. (1999). Interactions between Malaysia and Indonesian Palm Oil Industries: Simulating the Impact of Liberalization of Imports of CPO from Indonesia. Journal of Oil Palm Research, 11(2), 46-56.

Arshad, F.M., and Ghaffar, R.A. (1986). Stochastic Modelling of Crude Palm Oil Production Revisited. Occasional Paper. 11: Centre for Agricultural Policy Studies. University of Agriculture Malaysia.

Au, K., and Boyd, M.S. (1992). An Analysis of Supply Response, Exports Demand and Stocks for Malaysian Palm Oil. Malaysian Journal of Agricultural Economics, 9(1), 47-58.

Bank Negara Malaysia. (2009). Bank Negara Malaysia Annual Report 2008, P25.

Granger, C.W.J., and Newbold, P. (1974). Spurious Regressions in Econometrics. Journal of Econometrics, 2, 111-120.

Hwa, E.C. (1979). Price Determination in Several International Primary Commodity Markets: A Structural Analysis. IMF Staff Papers. 26, 157-188.

Labys, W.C. (1973). Dynamic Commodity Models: Specifications, Estimation and Simulation. Massachusettes: Lexington.

Labys, W.C., and Pollak, P.K. (1984). Commodity Models for Forecasting and Policy Analysis. New York: Nicholas Publishing Company.

Malaysian Palm Oil Board (MPOB). (2009). Economics and Industry Development Division Export Statistics. [Online] Available: http://econ.mpob.gov.my/economy/EID_web.htm. (21 January 2009 ).

Malaysian Palm Oil Council (MPOC) and Malaysian Palm Oil Board (MPOB). (2008). Fact Sheets on Malaysian Palm Oil.

Park, H., and Fortenbery, T. R. (2007). The Effect of Ethanol Production on the U.S National Corn Price. Proceedings of the NCCC-134 Conference on Applied Commodity Price Analysis, Forecasting and Market Risk Management. Chicago, IL. [Online] Available: http://www.farmdoc.uiuc.edu/nccc134/conf_2007/pdf/confp10-07.pdf. (18 December 2007).

Remali, Y., Chee, M. and Senteri, Z. (1998). Supply and Demand Model of the Malaysian Cocoa Industry. Borneo Review, 9(1), 67-86.

Robledo, C.W. (2002). Dynamic Econometric Modeling of the U.S Wheat Grain Market.PhD Dissertation. Louisiana State University.

Sekhar, C.S.C. (2003a). Price Formation in World Wheat Markets: Implications for Policy. Journal of Policy Modeling, 25(1), 85-106.

Sekhar, C.S.C. (2003b). Determinants of Price in World Wheat Markets-Hidden Lessons for Indian Policy Makers? Indian Economic Review, 38, 167-187.

Sekhar, C.S.C. (2008). Price Formation in World Soybean Oil Market: An Econometric Analysis. Indian Economic Review, 43(2), 183-204

Shamsudin, M. N., and Arshad, F.M. (1993). Malaysian Palm Oil Market Model. In Arshad, F.M., Shamsudin, M.N. and Othman, M.S. (Eds.) Malaysian Agricultural Commodity Forecasting and Policy Modelling. Center for Agricultural Policy Studies.

Shamsudin, M.N, Arshad, F.M., Mohamed, Z. A., and Lubis, A. R. (1994). A Market Model For Malaysian Palm Oil Industry. The Malaysian Journal of Agricultural Economics. 11(1), 81-102.

Shamsudin, M.N, Mohamed, Z.A and Arshad, F.M. (1988). Selected Factors Affecting Palm Oil Prices. Malaysian Journal of Agricultural Economics, 5(1), 20-29.

Shamsudin, M.N., Arshad, F.M., and Fuziah. (1997). The Effect of Export Duty Liberalization on the Palm Oil Industry. Malaysian Oil Science and Technology, 6(2), 79-82. 
Shri Dewi, A., Amna Awad Abdel Hameed, Shamsudin, M.N and Arshad, F.M. (2009a). An Econometric Model of the Malaysian Palm Oil Market, paper presented at the workshop on Agricultural Sector Modelling In Malaysia: Quantitative Models for Policy Analysis, organized by the Institut Kajian Dasar Pertanian dan Makanan, Universiti Putra Malaysia, Johor Bahru, 26-28 October.

Shri Dewi, A., and Alias, M.H. (2009). Rising Importance of Indonesian Palm Oil Production: Impact on the Malaysian Market. Muamalat Issue, 6(1), 2-5.

Shri Dewi, A., Arshad, F.M., Shamsudin, M.N., and Yusop, Z. (2008). The Impact of Biodiesel Demand on the Malaysian Palm Oil Economy: The Search for a Methodological Framework. Paper presented at the Seminar FEP 2008, Economics and Business-Towards a Sustainable Future, organized by Department of Economics, Faculty of Economics and Management, University Putra Malaysia, Hotel Mahkota, Melaka, 17-19 December 2008.

Shri Dewi, A., Arshad, F.M., Shamsudin, M.N., and Yusop, Z. (2010). The Impact of Biodiesel Demand on the Malaysian Palm Oil Market: A Combination of Econometric and System Dynamics Approach. Paper presented at the. International Conference on Business and Economic Research (ICBER), organized by Global Research Agency, Hilton Hotel, Kuching, Sarawak, 15-16 March 2010.

Shri Dewi, S., Alias, M.H., and Ali, A.M. (2007). Rising Assendency in Indonesian Production: Impact on the Malaysian Palm Oil Market. Jurnal Kinabalu, 13, 125-139.

Shri Dewi, S., Amna Awad Abdel Hameed, Shamsudin, M.N and Arshad, F.M. (2009b). Malaysian Palm Oil Modeling: A Combination of Econometric and System Dynamics Approach, Paper presented at the workshop on Agricultural Sector Modelling In Malaysia: Quantitative Models for Policy Analysis, organized by the Institut Kajian Dasar Pertanian dan Makanan, Universiti Putra Malaysia, Johor Bahru, 26-28 October.

Song, N. (2006). Structural Forecasting Softwood Lumber Models With Time Series Approach. PhD. Dissertation. Louisiana State University.

Talib, B.A., and Darawi, Z. (2002). An Economic Analysis of the Malaysian Palm Oil Market. Oil Palm Industry Economic Journal. 2(1), 19-27.

Talib, B.A., Jani, M.F.M., Mamat, M.N., and Zakaria, R. (2007). Impact Assessment of Liberalizing Trade on Malaysian Crude Palm Oil. Oil Palm Industry Economic Journal. 7(1), 9-17.

Taylor, R. D., Mattson, J. W., and Koo, W. K. (2006). Ethanol's Impact on the U.S Corn Industry. Agribusiness \& Applied Economics Report No. 580. Centre for Agricultural Policy and Trade Studies, Department of Agribusiness and Applied Economics North Dakota State University Fargo, North Dakota 58105-5636. [Online] Available: http://www.ag.ndsu.nodak.edu/capts/documents/AGReport580P.pdf. (12 December 2007).

Yusoff, M. (1988). Production and Trade Model for the Malaysian Palm-Oil Industry. Asean Economic Bulletin, 169-177. 
Table 1. Estimated Structural Equations

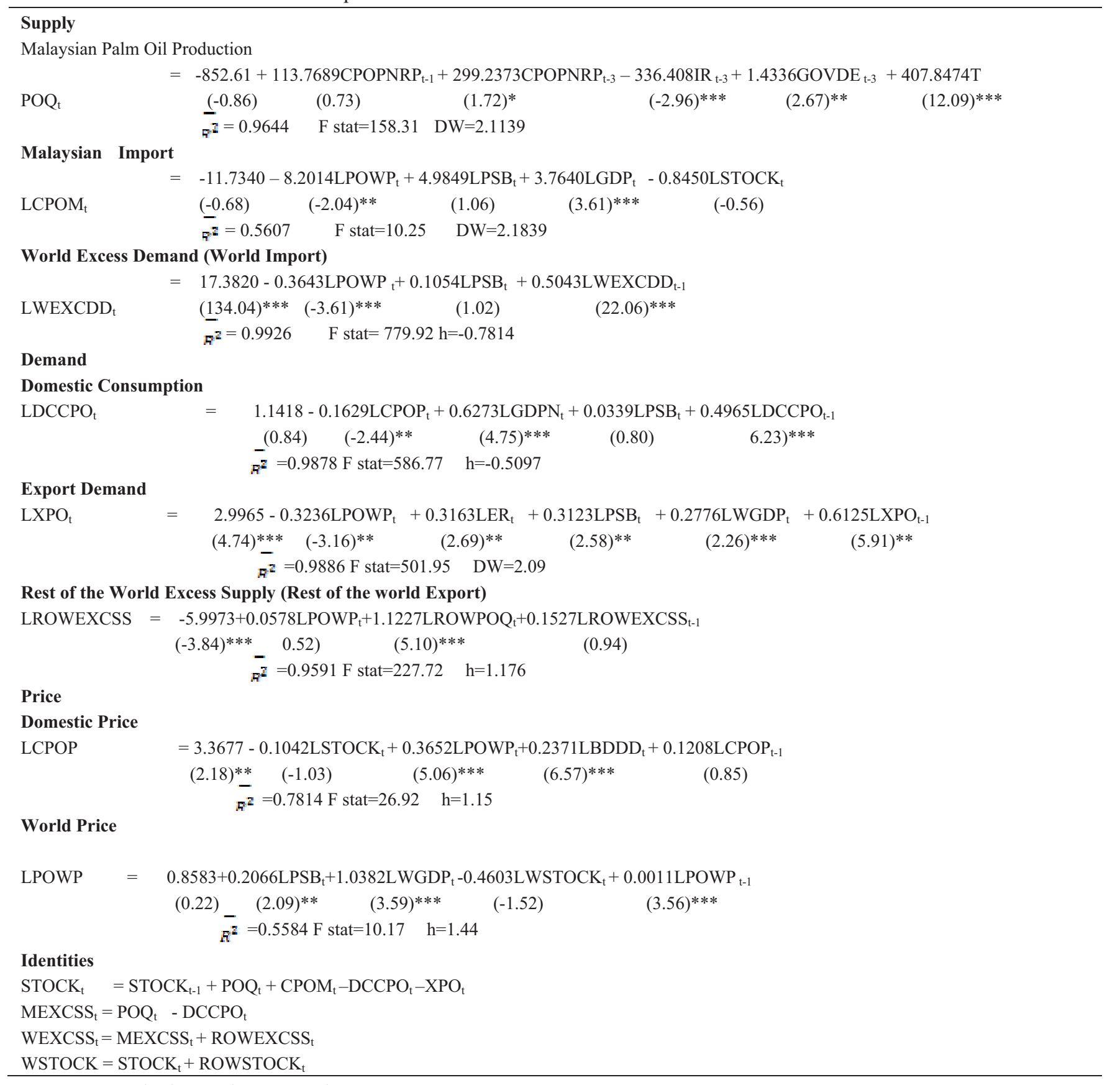

Note: Number in parentheses are $t$-values.

*** Significant at 1 percent level

** Significant at 5 percent level

* Significant at 10 percent level 